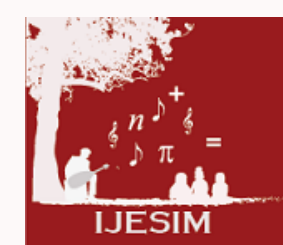

International Journal of Educational Studies in Mathematics

\title{
Attitude and Anxiety of Teacher Candidate on the Methods of Creative Drama
}

\author{
Esen Ersoy ${ }^{a}$, Belgin Bal İncebacak ${ }^{b}$
}

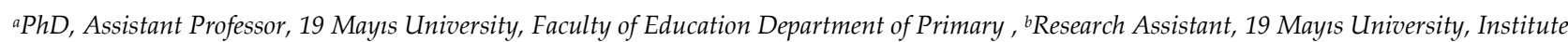
of Education Sciences

\section{ABSTRACT}

\begin{abstract}
Creative Drama Course, one of the active teaching methods, has been used in the study by the aim of determining which aspects might affect perspectives, concerns and attitudes of the students towards mathematics. In this study, we aimed to determine the attitudes and concerns of pre-service teachers towards mathematics who take Creative Drama course. As a data collection tool, "Creative Drama Attitude Scale" developed by Okvuran (2000) and "Mathematics Anxiety Scale" developed by Biber (2012) have been used in the study. We determined that the levels of attitude and anxiety of pre-service teachers did not suggest any significant difference in terms of gender factor. Besides, it has been concluded that the performed process with creative drama decreases the level of student's anxiety on Mathematics and positively affects their attitudes towards Mathematics as well. In conclusion, It can be said that the teaching method we used can be efficient in teaching.
\end{abstract}

Keywords:

Creative Drama, Attitude, Anxiety, Classroom Teaching, Mathematics Teaching.

(C) 2016 IJESIM. All rights reserved

Received 11.11.2015 Received in revised form 28.12.2015 Accepted 03.03.2016 Available online 30.03.2016

\section{Introduction}

(Mathematics remains a course of which the students feel fear and anxiety throughout the entire education years after they start school. There are many reasons that make up the math anxiety. According to Curtain (1999) there are three profound cases causing a lot of students to feel anxious in the classroom: teachers' authority, limitation of time and the pressure caused by expectations. In classrooms with these factors, the students feel under threat and develop negative attitudes. As negative attitudes are frequently replayed, anxiety begins to form. Teacher should review the teaching methods they use to reduce anxiety (Yenilmez, 2003). To overcome this situation, appropriate teaching methods and techniques should be used in mathematics courses, the students' attitudes, desires and interest in the course should be increased so as to reduce their anxiety levels. In many studies (Fiore, 1999; Dreger and Aiken, 1957; Fenner, and Sherman, 1976; Levine, 1995; Butterworth 1999), math anxiety is reported not to depend on a single cause. For this reason, active teaching methods should be involved in this process to eliminate the anxiety in math courses.

It is important that contemporary teaching methods should be involved in the process so that the individual can be at the center of learning (Ersoy, 2014). "Creative Drama" course, one of the active teaching method, has been involved in the process to eliminate the negative attitudes, anxieties and viewpoints.

\footnotetext{
${ }^{1}$ Corresponding author's address: 19 Mayıs University, Institute of Education Sciences, Samsun, TURKEY e-mail: belginbal33@gmail.com
}

DOI: http://dx.doi.org/10.17278/ijesim.2016.01.004 
It is essential that students be active in the constructivist educational process. Individual has a direct role in the warming-up, animation and evaluation in the method of creative drama, (Ersoy, 2014). The teaching created by using creative drama methods enables the students to acquire animations with their original ideas and thoughts and new and permanent learning.

\section{Method}

We used quantitative research method in the study. As we aimed to present the general situation of the participants on the subject in the study, we used Screening Model of Quantitative Research Methods. The aim of screening model is to gather the faith, attitudes, perspectives and views of the people on a current topic in education, and to define their behavior (Lodico, Spaulding \& Voegtle 2006).

\section{Study Group}

The study group is made up of total 157 students, 3rd grade $(\mathrm{n} 1=39)$, 4th class $(\mathrm{n} 1=38)$ of Classroom Teaching Department, Grade $2(n 1=40)$, 3rd year $(n 1=40)$ of Mathematics Department and taking Creative Drama course in the Faculty of Education, Ondokuz Mayıs University.

\section{Data Collection Tools}

In the study, we used "Creative Drama Attitude Scale" developed by Okvuran (2000) and "Mathematics Anxiety Scale" developed by Biber (2012) as data collection tools. Of those tools, "Creative Drama Attitude Scale" prepared by Okvuran (2000) with 45 items in 5-point-Likerts type was applied to measure the attitudes of the individuals towards creative drama. The highest score that can be taken from this scale is 255, the lowest score is 45. Also, "Mathematics Anxiety Scale" developed by Biber (2012) with 47 items in 5point-Likerts type was applied as a pre-test and post-test. The highest score from this scale is 235 , and the lowest score is 47 . The statistical analysis to examine the quantitative data collected in this study was done using software program 17 SPSS (Statistical Package for the Social Sciences). The frequency and percentages were calculated to analyze the data. Also, as independent samples, t-test was used, and the analysis with $\mathrm{p}=$ 0.05 of significance level were carried out. Measurement tools was administered to pre-service teachers before and after "Creative Drama" course.

\section{Problem Statement}

What are the anxiety levels and attitudes of the students taking "Creative Drama" course in the departments of Classroom Teaching and Elementary Mathematics Teaching towards Mathematics course?

\section{Sub-problems}

1. Is there a significant difference between the attitude scores of the 3rd grade and 4th grade students of Classroom Teaching Department who took creative drama class?

2. Is there a significant difference between the anxiety scores of the 3rd grade and 4th grade students of Classroom Teaching Department who took creative drama class?

3. Is there a significant difference between the attitude scores of the 2nd grade and 3rd grade students of Elementary Mathematics Teaching Department who took creative drama class?

4. Is there a significant difference between the anxiety scores of the 2 nd grade and 3rd grade students of Elementary Mathematics Teaching Department who took creative drama class?

\section{Findings}

Normality distribution points are included in the table below in view of attitude and anxiety points of the students in Classroom Teaching and Elementary Mathematics Teaching Departments taking creative drama course.

Tablo 1. Normality Distribution of Departments (Shapiro-Wilk's Values)

\begin{tabular}{c|c|c}
\hline & Test Statistics $(\mathrm{W})$ & Test Statistics $(\mathrm{W})$ \\
\hline Study Groups & Attitude & Anxiety \\
\hline Classroom Teaching & 0.966 & 0.978 \\
\hline Elementary Mathematics Teaching & 0.925 & 0.978 \\
\hline
\end{tabular}


W Test Statistics were calculated to determine whether or not they are normally distributed data. We test statistic varies in the range of $0<\mathrm{W} \leq 1$. The values closer to 1 show that variable has normal distribution, whereas those closer to 0 show that variable doesn't have normal distribution (Ozdamar, 2004). As seen in the table above the data are normally distributed.

\section{Findings Related to the First Sub Problem}

The findings as to whether there is a significant difference between the attitude scores of the 3rd grade and 4th grade students of Classroom Teaching Department who took creative drama class are as follows;

Table 2. Independent $t$-Test scores of attitude levels of the students in the 3 rd grade and 4 th grade of Classroom Teaching Department who took creative drama class

\begin{tabular}{c|c|c|c|c}
\hline Classroom teaching/Attitude & $\mathrm{N}$ & $\overline{\mathrm{X}}$ & $\mathrm{Ss}$ & $\mathrm{p}$ \\
\hline 3rd grade & 39 & 167,58 & 27,67 & \multirow{2}{*}{0,289} \\
\hline 4th grade & 38 & 162,60 & 20,26 & \\
\hline
\end{tabular}

When Table 2 is examined, the attitude scores of the 3rd grade students in the Classroom Teaching Department taking the Drama Course seem to be higher when examining their attitudes points. It is thought that the decline in the attitude of 4th grade students towards Drama Course may adversely affect their attitudes due to the approaching graduation.

\section{Findings Related to the Second Sub Problem}

The findings as to whether there is a significant difference between the attitude scores of the 3rd grade and 4th grade students of Classroom Teaching Department who took Creative Drama Course are as follows;

Table 3. Independent t-Test scores of anxiety points of the students in the 3 rd grade and 4 th grade of Classroom Teaching Department who took creative drama class

\begin{tabular}{c|c|c|c|c}
\hline Classroom Teaching/Anxiety & $\mathrm{N}$ & $\overline{\mathrm{X}}$ & $\mathrm{Ss}$ & $\mathrm{p}$ \\
\hline 3rd Grade & 39 & 144,42 & 24,39 & \multirow{2}{*}{0,341} \\
\hline 4th Grade & 38 & 139,46 & 20,98 & \\
\hline
\end{tabular}

When Table 3 is examined, the anxiety scores of the 3rd grade students taking the course in the Classroom Teaching Department are found to be 144,42 , while the 4 th grade students to be 139,46 . The highest score of the scale is 235 , however the mean point measured from the scale is found to be between 144,42 and 139,46. We determined that there is a decresa in anxiety scores of the students towards Mathematics taking Creative Drama Course. Of the Alternative Teaching Methods conducted in accordance with constructivist approach, the use of Creative Drama in Mathematics is thought to reduce anxiety level of the students.

\section{Findings Related to the Third Sub Problem}

The findings as to whether there is a significant difference between the attitude scores of the 2nd grade and 3rd grade students of Elementary Mathematics Teaching Department who took Creative Drama Course are as follows;

Table 4. Independent $t$-Test scores of attitude levels of the students in the 2 nd grade and 3 rd grade of Elementary MathematicsTeaching Department who took creative drama class

\begin{tabular}{c|c|c|c|c}
\hline $\begin{array}{c}\text { Elementary Mathematics } \\
\text { Teaching/Attitude }\end{array}$ & $\mathrm{N}$ & $\overline{\mathrm{X}}$ & $\mathrm{Ss}$ & $\mathrm{p}$ \\
\hline 2nd Grade & 40 & 173,70 & 25,35 & \multirow{2}{*}{0,975} \\
\hline 3rd Grade & 40 & 173,50 & 24,15 & \\
\hline
\end{tabular}

When Table 4 is examined, the attitude scores of the 3rd grade students in the Elementary Mathematics Teaching Department taking the Drama Course seem to be similar when examining their attitudes points. Their attitudes towards mathematics are positive as they are students in Mathematics Department and they 
do not change as to their grades. The highest score that can be taken from this scale is 255 , the lowest score is 45. It is observed that students have high scores range based on this score range.

\section{Findings Related to the Fourth Sub Problem}

The findings as to whether there is a significant difference between the anxiety scores of the 2nd grade and 3rd grade students of Elementary Mathematics Teaching Department who took Creative Drama Course are as follows;

Table 5. Independent $t$-Test scores of anxiety points of the students in the 2 nd grade and $3 \mathrm{rd}$ grade of Elementary MathematicsTeaching Department who took creative drama class

\begin{tabular}{c|c|c|c|c}
\hline $\begin{array}{c}\text { Elementary Mathematics } \\
\text { Teaching/Anxiety }\end{array}$ & $\mathrm{N}$ & $\overline{\mathrm{X}}$ & $\mathrm{Ss}$ & $\mathrm{p}$ \\
\hline 2nd Grade & 40 & 142,22 & 21,13 & \multirow{2}{*}{0,761} \\
\hline 3rd Grade & 40 & 137,72 & 20,79 & \\
\hline
\end{tabular}

When Table 5 is examined, the average anxiety scores of the 2nd grade in the Classroom Teaching Department students taking the Drama Course are found to be 142,22, while the 3rd grade students to be 137,72 . The anxiety state of the students seem to increase toward upper grades. As the lowest point to get from this scale is 47 , anxiety scores are seen to be relatively higher.

\section{Results}

Considering the results of our study, the anxiety was found to be higher in upper grades students in both departments. The upper the grades of the students are, the higher the anxiety scores are due to the reasons such as beginning of a new life. Anxiety levels of the students were observed to reduce in the period of their attendance to Creative Drama Course. Likewise, Aydin, Delice, Dilmac \& Ertekin (2009), reported in their study that anxiety states of the students toward mathematics are different from each grade and decrease in anxiety levels.

Baykul (1990), in his study, emphasized that positive attitudes of elementary school students in the fifth grade towards the courses tend to decrease in upper grades, and the underlying reason might be the available teaching methods and teachers behaviors. Likewise, Bertiz, Bahar \& Yegen (2010), state in their study on Science and technology pre-service teachers that attitude scores of the students decrease to the upper grades. In our study, the average scores of the students' attitudes in the period of their attendance to Creative Drama Course are high, while their average scores of attitude seem to decrease to the upper grades.

Bekdemir \& et al. (2004) stated that the attitudes of the teachers affect the interest of students in Mathematics, and any effect of negative experience with their teachers would be heavy and permanent. In some studies Mathematics anxiety is stated to last twelve years or so (Jackson \& Leffingel, 1999). The process with Creative Drama Course has been observed to reduce anxiety levels of the students towards Mathematics. Of the Alternative Teaching Methods, the use of Creative Drama in education was found to reduce anxiety levels of the students. Consequently, the method of Creative Drama Teaching can be said to be effective in teaching.

\section{References}

Aydın, E., Delice, A., Dilmaç, B. \& Ertekin, E. (2009). İlköğretim Matematik Öğretmen Adayların Matematik Kayg1 Düzeylerine Cinsiyet, Sınıf ve Kurum Değişkenlerinin Etkileri. İlköğretim Online. 8 (1). 231-242.

Baykul, Y. (1990). İlkokul Beşinci Sinıftan Lise ve Dengi Okulların Son Sımıfina Kadar Matematik ve Fen Derslerine Karşı Tutumda Görülen Değişmeler ve Öğrenci Yerleştirme Sınavındaki Başarı ile İlişkili Olduğu Düşünülen Bazı Faktörler. Ankara: ÖSYM Yayınları.

Bekdemir, M., A. Işık, Y. Çıkılı. (2004). Matematik Kaygısını Oluşturan ve Artıran Öğretmen Davranışları ve Çözüm Yolları, Ĕ̆itim Araştırmaları Dergisi, 4 (16), 88-89.

Bertiz, H., Bahar, M., \& Yeğeni G. (2010). Fen ve Teknoloji Öğretmen Adaylarının Yaratıcı Drama Yöntemine Yönelik Tutumları ve Yöntemin Fen ve Teknoloji Eğitiminde Kullanılabilirliğine İlişkin Görüşleri. Gazi Ĕ̆itim Fakültesi Dergisi, 30 (2), 483-509. 
Biber, M. (2012). Duyuşsal Özelliklerin Probleme Dayalı Öğrenme Sürecinde Öğrencilerin Matematiksel Kazanımlarına Etkisi. (Yayımlanmamış Doktora Tezi). Dokuz Eylül Üniversitesi, Eğitim Bilimleri Enstitüsü, İzmir.

Butterworth, B. (1999). The Mathematical Brain. London: Macmillan.

Büyüköztürk, Ş. (2003) Veri Analizi El Kitabı. Ankara: Pegem Yayınları.

Büyüköztürk, Ş., Çakmak, E. K., Akgün, Ö. E., Karadeniz, Ş., \& Demirel, F. (2011). Bilimsel Araştırma Yöntemleri. Ankara: Pegem yayıncilık.

Creswell, J.W. (2007). Qualitative Inquiry and Research Desing: Choosing Among Five Approaches (2nd ed.). Thousand Oaks, CA: Sage

Curtain, M. (1999). How to Reduce Math Anxiety in the Classroom at Work and in Everyday Personal Use.New York: Paperback.

Dreger, R. M., \& Aiken, L. R. (1957). The identification of number anxiety in a college population. Journal of Educational Psychology, 48, 344-351.

Eldemir, H. H. (2006). Sınıf Öğretmeni Adaylarının Matematik Kaygısının Bazı Psiko-sosyal Değişkenler Açısından İncelenmesi. (Yayımlanmamış Yüksek lisans tezi), Cumhuriyet Üniversitesi, Sosyal Bilimler Enstitüsü, Sivas.

Ersoy, E. (2014). Geometri Öğretiminde Yaratıcı Dramanın Etkisi. Turkish Studies-International Periodical For The Languages, Literature and History of Turkish or Turkic. 9 (5). 929-942.

Fennema, E., \& Sherman, J. A. (1976). Fennema-Sherman Mathematics Attitudes Scales: Instruments Designed to Measure Attitudes toward The Learning of Mathematics by Females and Males. Journal for Research in Mathematics Education, 7 (5), 324-326.

Fiore, G. (1999). Math-abused students: Are we prepared to teach them?, The Mathematics Teacher, 90 (5), 403406.

Jackson, C., \& Leffingwell, R. (1999). The role of instructors in creating math anxiety in students from kindergarten through college. Mathematics Teacher, 92 (7), 583-587. (ERIC Document Reproduction Service No. ED 431 628)

Karasar, N. (2008). Bilimsel Araştırma Yöntemi. Ankara: Nobel Yayıncılık.

Levine, D. N. (1995). The Organism Metaphor in Sociology. Social Research: An International Quarterly, The Power of Metaphor (Edt: Arien Mack), 62 (3), 239-265.

Lodico, M. G., Spaulding, D. T. \& Voegtle, K. H. (2006). Methods in educational research: From theory to practice. San Francisco: Jossey-Bass

Okvuran, A. (2000). Yaratıcı Dramaya Yönelik Tutumlar. (Yayımlanmamış Doktora Tezi), Ankara Üniversitesi Sosyal Bilimler Enstitüsü, Ankara.

Özdamar, K. (2004). Paket Programlar İle İstatistiksel Veri Analizi-1. MINITAB- NCSS-SPSS. Genişletilmiş 5. Baskı. Eskişehir: Kaan Kitabevi.

Üldaş, İ. (2005). Öğretmen ve Öğretmen Adaylarına Yönelik Matematik Kaygı Ölçeği (MKÖ-Ö)'nin Geliştirilmesi ve Matematik Kaygısına İlişkin Bir Değerlendirme. (Yüksek Lisans Tezi). Marmara Üniversitesi, Eğitim Bilimleri Enstitüsü, İstanbul.

Yenilmez, K. \& Özbey, N. (2006). Özel Okul ve Devlet Okulu Öğrencilerinin Matematik Kaygı Düzeyleri Üzerine Bir Araştırma. Ĕ̆itim Fakültesi Dergisi, 29 (2), 431-448.

Yüksel Şahin, F. (2004). Ortaöğretim Öğrencilerinin ve Üniversite Öğrencilerinin Matematik Korku Düzeyleri. Educational Sciences and Practice, 3 (5). 57-74. 